МАРКЕТИНГ

УДК 005.334:502

О. М. Коробець, провідний фахівець

\section{БІБЛІОМЕТРИЧНИЙ АНАЛІЗ ВЗАЄМОЗВ'ЯЗКУ ПОНЯТЬ «ЕКОЛОГІЧНИЙ РИЗИК» ТА «МАРКЕТИНГ»}

Актуальність теми дослідження викликана зростанням публікаційної активності в області екологічного ризику, та пошуком взаємопов'язаних перспективних напрямків майбутніх досліджень.

Постановка проблеми. В зв'язку зі збереженням тенденцій виникнення надзвичайних ситуацій, увага до вирішення проблем врахування екологічного ризику не втрачає актуальності серед дослідників різних наукових сорер. Зростання публікаційної активності дозволило накопичити значну базу даних, розгляд якої за допомогою методів бібліометричного аналізу може виявити нові напрями досліджень.

Аналіз останніх досліджень і публікацій. За останні десятиліття дослідженню екологічних ризиків присвячені роботи багатьох зарубіжних та вітчизняних вчених. Взаємозв'язок між маркетингом та навколишнім середовищем $є$ иентральною темою дискусій щодо маркетингу стійкості.

Виділення недосліджених частин загальної проблеми. Зміни, що відбуваються в розвитку сучасної економіки підштовхують до пошуку нових методів впливу на екологічні ризики. Одним з перспективних напрямів вважаються маркетингові інструменти управління екологічними ризиками.

Постановка завдання. Аналіз поняття «екологічний ризик», формування його складових елементів, та виявлення наявності маркетингових складових в його структурі.

Виклад основного матеріалу. У статті проведено бібліометричний аналіз понять «екологічний ризик» та «маркетинг». Для аналізу було визначено динаміку частоти застосування запиту «екологічний ризик» в пошукових системах, та динаміку публікаційної активності за даним поняттям в базах даних Scopus, за період 2005-2019 р.р. На основі відібраних публікацій за допомогою програми VOSviewer побудовані термінологічні карти за обраними поняттями, та виявлені їх основні точки перетину.

Висновки. За результатами дослідження виявлено зниження, але стійке збереження уваги до проблем врахування екологічного ризику в діяльності суб'єктів господарювання. Обгрунтовано $і$ пошагово описана методика дослідження поняття «екологічний ризик» 3 точки зору його сутності та структури. Чітка візуалізація дала можливість виділити маркетингові складові, що можуть впливати на екологічний ризик.

Ключові слова: маркетинг; екологічний ризик; бібліометричний аналіз; запит; публікації; активність; термінологічна карта.

DOI: $10.25140 / 2410-9576-2020-2-1(20)-104-110$

Актуальність теми дослідження. Застосування бібліометричних інструментів аналізу даних дозволяють працювати зі значною кількістю публікацій, що дає можливість визначити тенденції
Urgency of the research is caused by the growth of publishing activity in the field of environmental risk, and the search for interconnected promising areas of future research.

Target setting. In connection with the persistence of trends in emergencies, attention to solving problems of environmental risk does not lose relevance among researchers of various scientific fields. The growth of publishing activity has allowed to accumulate a significant database, the consideration of which with the help of bibliometric analysis methods can reveal new areas of research.

Actual scientific researches and issues analysis. In recent decades, the work of many foreign and domestic scientists has been devoted to the study of environmental risks. The relationship between marketing and the environment is a central topic of discussion about sustainability marketing.

Uninvestigated parts of general matters defining. Changes in the development of the modern economy encourage the search for new methods of influencing environmental risks. One of the promising areas is marketing tools for environmental risk management.

The research objective. Analysis of the concept "environmental risk", formation of its constituent elements, and identifying the availability and frequency of marketing tools in its structure.

The statement of basic materials. The study conducted a bibliometric analysis of "environmental results" and "marketing" concepts. For the analysis, the dynamics of frequency of application the query "environmental risk" in search engines, and the dynamics of publication activity on this concept in Scopus databases for the period 2005-2019 were determined. On the basis of selected publications with the help of VOSviewer the terminological maps on the chosen concepts are constructed, and their basic points of intersection are revealed.

Conclusions. The results of study revealed a decrease, but stable maintenance of attention to the problems of taking into account environmental risk in the activities of economic entities. The method of research of the concept of "ecological risk" from the point of view of its essence and structure is substantiated and step by step described. Clearly visualization made it possible to identify marketing components that may affect environmental risk.

Keywords: marketing; environmental risk; bibliometric analysis; query; publications; activity; terminology map. 
в дослідницькій діяльності, які важко досягти без застосування спеціальних засобів. Даний метод аналізу дозволяє визначати напрямки дослідження з необхідним ступенем глибини і деталізації, та виявити закономірності в публікаційній активності вчених різних країн світу.

Постановка проблеми. Дослідження в області екологічного ризику сформувалися наприкінці минулого століття. Однак, в зв'язку зі збереженням тенденцій виникнення надзвичайних ситуацій, увага до вирішення даного питання не втрачає актуальності серед дослідників різних наукових сфрер і сьогодні. Зростання публікаційної активності дозволило накопичити значну базу даних для пошуку та виявлення взаємопов'язаних перспективних напрямків майбутніх досліджень.

Аналіз останніх досліджень і публікацій. За останні десятиліття дослідженню екологічних ризиків присвячені роботи багатьох зарубіжних (Бек У. [1], Піку С., Маршалл Б. [2], Хейт Д. [3], Бурков В. М. [4], Тепман Л. Н. [5], Шмаль А.Г. [6] та ін.) та вітчизняних (Качинський А. Б. [7], Козьменко О. В. [8], Таранюк К. В. [9], Караєва Н. В. [10] та ін.) вчених. Однак, огляд публікацій, показує, що серед дослідників немає єдиної думки щодо визначення ризику і однозначного розуміння сутності ризику.

Взаємозв'язок між маркетингом та навколишнім середовищем є центральною темою дискусій щодо маркетингу стійкості (Белз Ф., Пітті К., [11], Макдональд С. [12], Протеро А., Фітчетт Дж. [13], Ретті Р. [14]). Попередні дослідження підходили до цього взаємозв'язку за допомогою ряду взаємозамінних концепцій, таких як «зелений маркетинг» (Кілбурн В. [15], Пітті К., Крен А. [16]), «екологічний виробничий маркетинг» (Менон А. [17]) та «стійкий маркетинг» (Гордон, Р. [18]).

Виділення недосліджених частин загальної проблеми. Зміни, що відбуваються в розвитку сучасної економіки підштовхують до пошуку нових методів впливу на екологічні ризики. Одним 3 перспективних напрямів вважаються маркетингові інструменти управління екологічними ризиками.

Постановка завдання. Проведення бібліометричного аналізу поняття «екологічний ризик», та виявлення маркетингової складової в його структурі.

Викладення основного матеріалу. Джерело появи слова «ризик» невідоме. Вважається, що слово ризик походить від арабського слова «risk», або латинського «risiqum». Перше означає щось, що дано вищими силами і за допомогою чого можна отримати вигоду, друге - відносилося до виклику, який риф кидав моряку. Тобто первісно поняття ризику виражалося в двох загальних значеннях - як дія, що призведе до позитивного результату, або ж як можливість небезпеки, невдачі, втрати.

Сьогодні поняття «екологічний ризик» активно вивчається представниками різних наукових областей. Але при цьому воно досі не має однозначного поняття. Так для аналізу екологічного ризику в англійській мові використовують як синоніми такі терміни - environmental risk, ecological risk, ecorisk.

Пошук найбільш релевантної інформації для визначення сутності поняття екологічний ризик проходив у декілька етапів.

Перший етап складався з визначення частоти застосування запиту «екологічний ризик». При цьому, оскільки термін розглядався в масштабах всіх країн світу, пошуковий запит включав варіанти різними мовами. Тому для пошуку біли використані наступні ключові слова: синоніми загальноприйнятою міжнародною мовою (англійською) - «environmental risk», «ecological risk», «еcorisk», найбільшою слов'янською мовою (російською) - «экологический риск», та державною (українською) - «екологічний ризик».

Визначення частоти застосування запитів в пошукових системах здійснювалося за допомогою інструменту Google Trends. Це публічний додаток, що відображає на основні пошукової системи Google частоту пошукової популярності певного терміну по відношенню до загального обсягу пошукових запитів в різних регіонах світу та різними мовами. Даний інструмент має обмеження в періоді відбору даних, та починається з 2004 року.

Для дослідження було обрано період з 2005 по 2019 роки. Ознайомитися з динамікою частоти пошуку терміну «екологічний ризик» можна на (Рис. 1). 


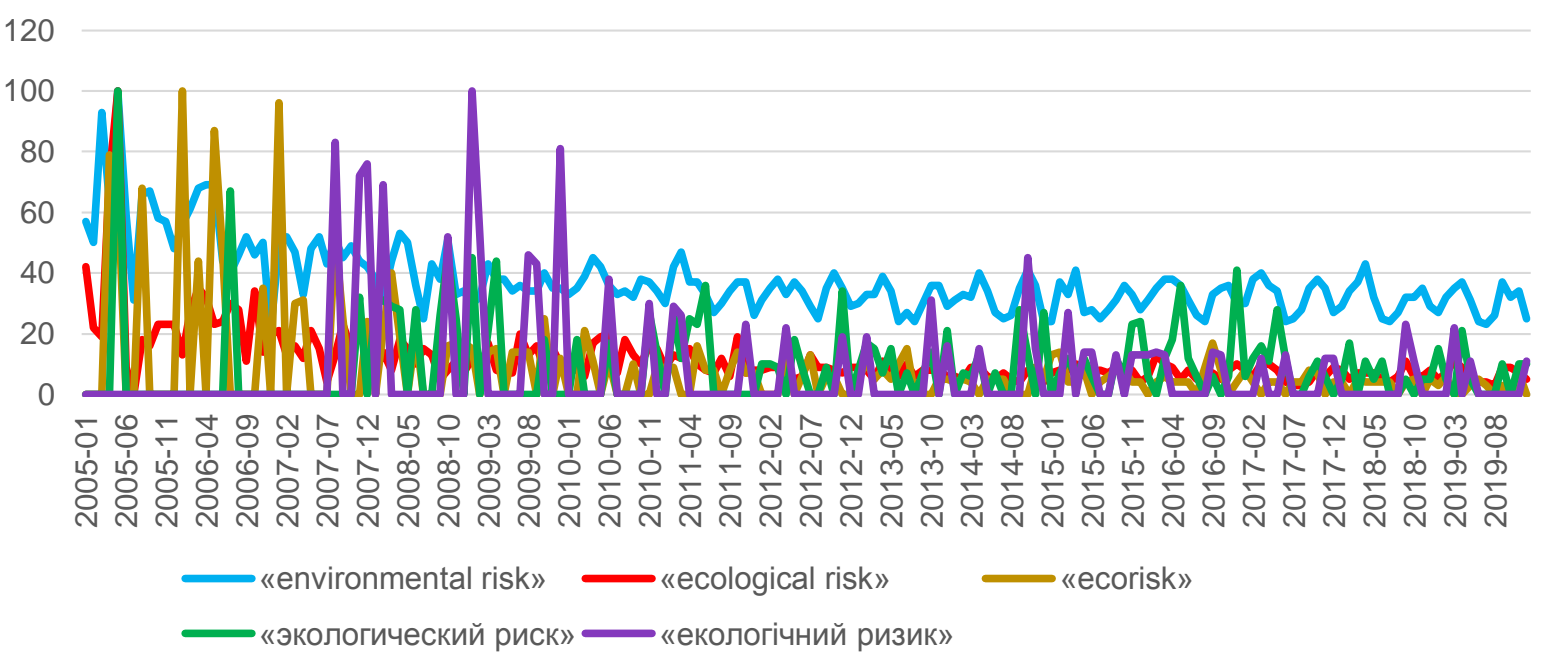

Рис. 1 Динаміка частоти застосування запиту «екологічний ризик» в пошукових системах за період 2005-2019 p.p. (побудовано автором за допомогою інструменту Google Trends)

Як бачимо, найбільша пошукова активність за всіма термінами спостерігається в період 3 2005 по 2009 роки. Спочатку популярності запитів набирають англомовні терміни, потім слов'яномовні. Але не зважаючи на зниження динаміки запитів з 2010 року, все ж таки тенденція залишається стабільною протягом останніх 10 років.

Найбільша кількість запитів була зроблена за англомовним терміном з таких країн - Кенія (100\%), Південно-Африканська Республіка (86\%), Австралія (82\%), Нігерія (76\%), США (72\%), та за російськомовними - Росія (100\%), Казахстан (76\%).

Оскільки англомовні терміни повторювалися в ряді країн, то для аналізу було вирішено використовувати їх середнє значення. Застосування терміну «екологічний ризик» українською мовою по відношенню до англомовних та російськомовних $€$ дуже низьким.

На другому етапі було проаналізовано публікації, які вивчають різні аспекти екологічного ризику. Для відображення динаміки публікаційної активності було відібрано статті в базі даних Scopus за ключовими словами, що відповідають синонімам англомовного терміну «екологічний ризик». Так, якщо на початку обраного періоду, в 2005 році було опубліковано 81 стаття, то в 2019 році це вже 234 (Рис. 2). Тобто кількість публікацій за 15 років збільшилася майже в 3 рази.

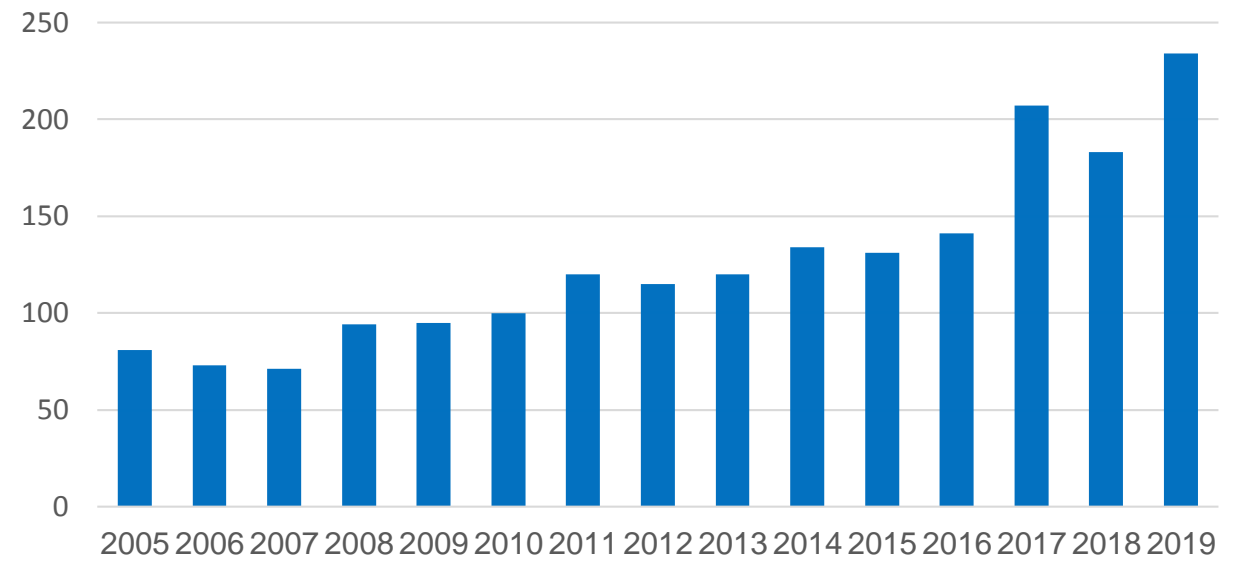

Рис. 2 Динаміка публікаційної активності з вивчення екологічних ризиків за період 2005-2019 р.p. (побудовано автором на основі бази даних Scopus)

Коробець О. М. Бібліометричний аналіз взаємозв'язку понять «екологічний ризик» та «маркетинг» 


\section{МАРКЕТИНГ}

Третій етап був присвячений виявлення тенденцій та закономірностей в публікаційній активності вчених різних країн. Для цього було застосовано метод бібліометричного аналізу. Даний метод використовується по-перше для аналізу ефективності наукових досліджень, а подруге для картування досліджень. При цьому ефеективності наукових робіт спрямований на оцінювання результатів досліджень і публікацій за окремими авторами, організаціями, країнами. Картування ж направлено на визначення структури і динаміки наукових областей досліджень.

Для аналізу відібрано 1899 статей в базі даних Scopus протягом 2005-2019 р.p. Аналіз проводився за допомогою програми VOSviewer.

Спершу було проаналізовано дослідження за країнами їх публікацій, для того щоб виявити ряд країн, на які буде спрямована першочергова увага. Найбільша кількість статей була опублікована в США (23\%), Китаї (11\%), Великобританії (11\%), Канаді $(6 \%)$, Австралії $(6 \%)$, Німеччині (5\%), Франції (5\%), Нідерландах (4\%), Італії (4\%), Швеції (3\%). При цьому, найбільш ранні публікації найчастіше зустрічаються у таких країнах - США, Великобританія, Канада, Франція, Швеція. Кількість публікацій в Україні складає - 7 (0,37\%).

За допомогою програми VOSviewer також було вивчене тематичну спрямованість публікацій, яка дозволила побудувати термінологічну карту на основі термінів, що зустрічаються в ключових словах та анотаціях статей (Рис. 3).

Отримані результати дозволили виділити 4 найбільші кластери, що об'єднують ключові поняття по тематичній близькості. Дана карта показує частоту використання термінів (величина кола), тісноту зав'язків між ними (чим ближче, тим тісніше) і різні варіанти поєднань термінів як всередині кластерів, так і між ними.

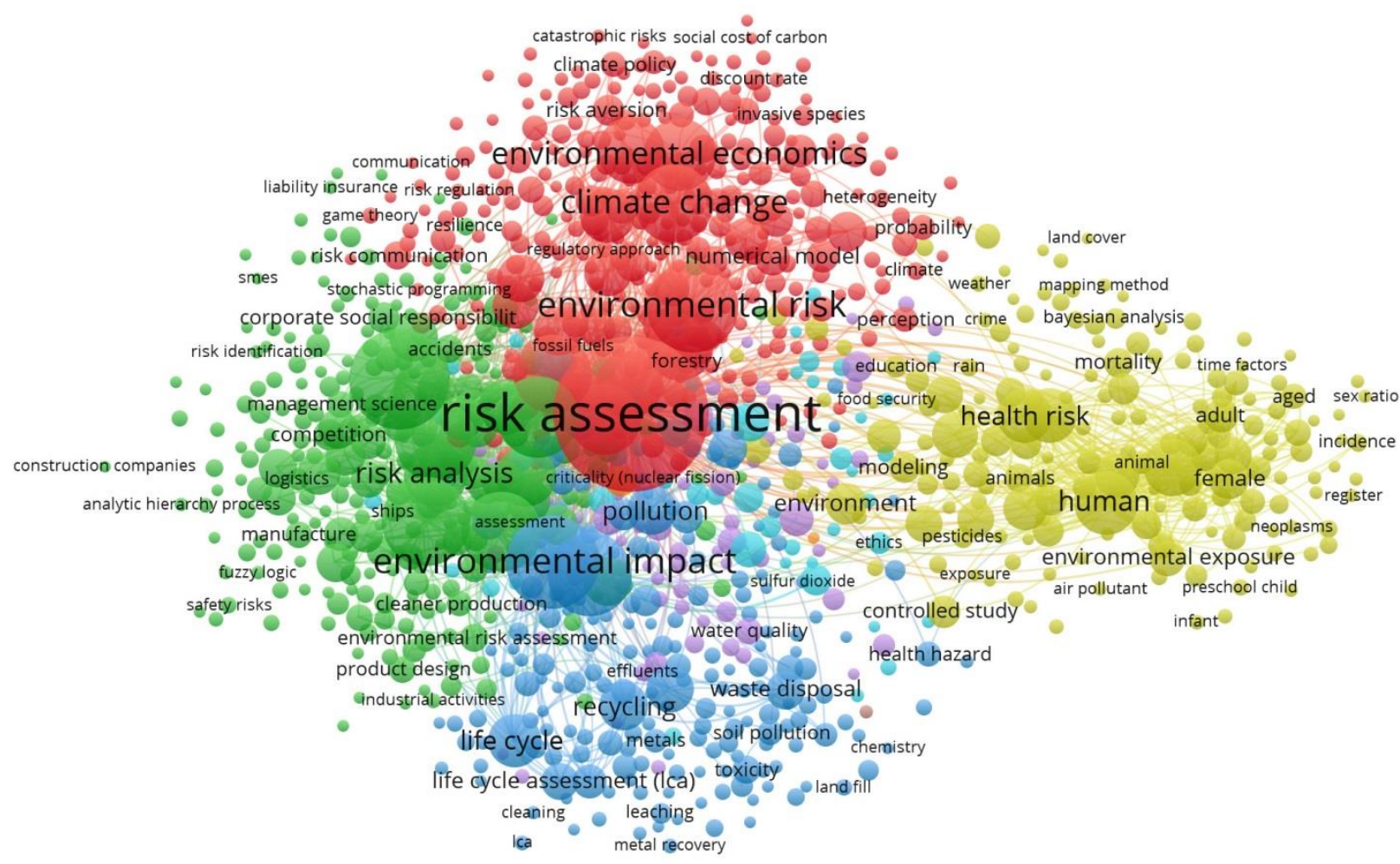

Рис. 3 Термінологічна карта публікацій з вивчення екологічних ризиків за період 2005-2019 р.р. (побудовано автором за допомогою інструменту VOSviewer)

Найбільшим виявився кластер червоного кольору. Цей кластер отримав умовну назву «оцінка ризику», оскільки включає в себе поняття: ймовірність, підхід, метод, модель тощо. 


\section{МАРКЕТИНГ}

Зелений кластер є другим по величині. Його було позначено як «управління ризиками». В даному кластері ключовими термінами є: аналіз, менеджмент, відповідальність, і т.п. Синій та жовтий кластери є приблизно однаковими по величині. В синьому кластері частіше за все зустрічаються терміни, що є результатом діяльності підприємства: вплив, забруднення, відходи, життєвий цикл, і т.п. Цьому кластеру біло присвоєно назву «діяльність підприємства». Жовтий же кластер на відміну від синього показує сукупність об'єктів та суб'єктів навколишнього природного середовища на яких здійснюється вплив: людина, здоров'я, тварина, земля, повітря, вода, ліс, і т.п. Він отримав назву «вплив на навколишнє природне середовище».

При аналізі публікацій та формуванні термінологічної карти можна звернути увагу, що в кластерах «управління ризиками» та «діяльність підприємства» 3 доволі високою частотою зустрічаються поняття: комунікація, конкуренція, життєвий цикл товару, дизайн продукції. Тобто ці показники мають взаємодію та вплив на екологічні ризики. Тому для формування подальшого дослідження було прийнято рішення проаналізувати публікації, що мають ключові слова 3 термінами «екологічний ризик» та «маркетинг».

За базою даних Scopus було виявлено 164 публікації, що включали в себе обрані поняття. Та за допомогою програми VOSviewer знову була побудована термінологічна карта (Рис. 4).

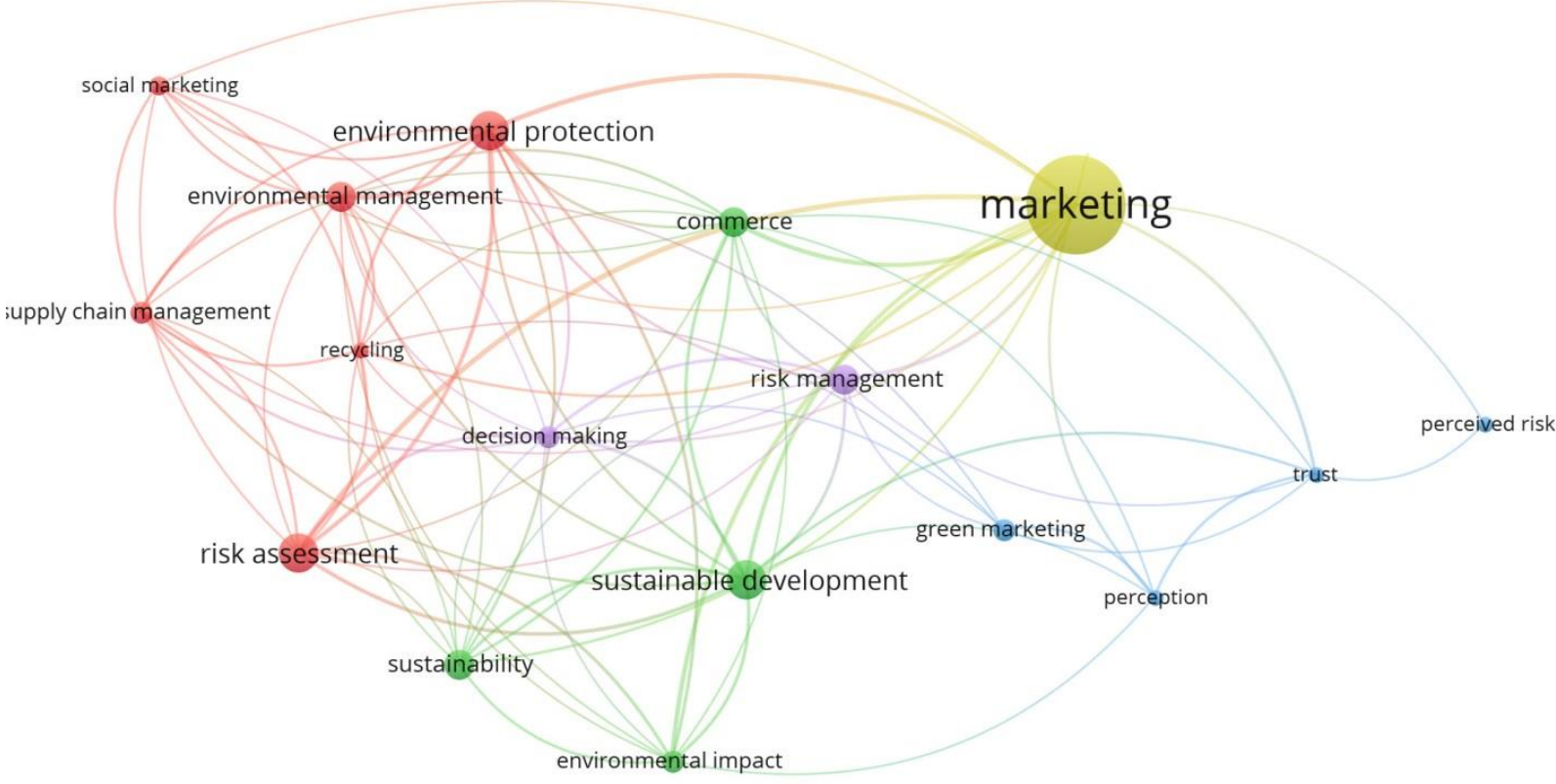

Рис. 4 Термінологічна карта публікацій взаємозв'язку визначень екологічних ризиків та маркетинг за період 2005-2019 р.р. (побудовано автором за допомогою інструменту VOSviewer)

За даними (Рис. 4) бачимо найбільш значимий зв'язок маркетингу з захистом навколишнього середовища, оцінкою ризику, стійким розвитком, управлінням ризиком. При цьому дослідження взаємозв'язків з захистом навколишнього середовища, оцінкою ризику, управлінням ризиком, впливом на навколишнє середовище, прийняття рішень, ведуться з початку аналізованого періоду.

Висновки. Результати проведеного дослідження дали можливість підтвердити доцільність застосування інструментів бібліометричного аналізу публікацій. Виявлено, що вони мають різні дослідницькі можливості та доповнюють однин одного.

Аналіз наукових досліджень екологічного ризику проведені за період 2005-2019 р.р. на основі бази даних Scopus за допомогою програми VOSviewer дозволили виділити та візуалізувати 4 основні кластери досліджень: оцінка ризику, управління ризиками, діяльність підприємства, 
МАРКЕТИНГ

вплив на навколишнє природне середовище. На основі сформованих кластерів були виявлені та розглянуті маркетингові складові, що можуть впливати на екологічний ризик. Виявлений взаємозв'язок $є$ обґрунтованим напрямом для подальших досліджень.

Фінансування. Дослідження фінансувалось грантом Міністерства освіти і науки України (№0117U003932).

\section{Література}

1. Beck, W. (2000). Risk Society. On the way to another Art Nouveau.

2. Picou, J. S., Marshall, B. K. (2002). Contemporary conceptions of environmental risk: Implications for resource management and policy. Sociological Practice, 4(4), p. 293-313.

3. Hyett, D. (2010,). Environmental risk assessment in environmental impact assessment-optional or mandatory? In IAIA10 Conference Proceedings: The Role of Impact Assessment in Transitioning to the Green Economy. 30th Annual Meeting of the International Association for Impact Assessment (p. 6-11).

4. Бурков, В. Н., Новиков, Д. А., Щепкин, А. В. (2008). Механизмы управления эколого-экономическими системами. М.: Физматлит.

5. Тэпман, Л. Н. (2002). Риски в экономике. М.: ЮНИТИ.

6. Шмаль, А. Г. (2010). Факторы экологической опасности \& экологические риски. МУП «Бронницкие новостиТелевидение».

7. Качинський, А. Б. (2001). Екологічна безпека України: системний аналіз перспектив покращення. К.: НІСД, 310(1)

8. Козьменко, О. В. (2008). Страховий ринок України у контексті сталого розвитку.

9. Таранюк, К. В. (2014). Організаційно-економічні основи управління екологічним ризиком на регіональному рівні : дис. - Вид-во СумДУ, 2014.

10. Караєва, Н. В., Войтко, С. В., Сорокіна, Л. В. (2013). Ризик-менеджмент сталого розвитку енергетики: інсоормаційна підтримка прийняття рішень. - Електронний pecypc : https://www.voytko.kpi.in.ua.

11. Belz, F. M., Peattie, K. (2009). Sustainability marketing: A global perspective. Chichester: Wiley.

12. McDonald, S., Oates, C. J., Alevizou, P. J., Young, C. W., Hwang, K. (2012). Individual strategies for sustainable consumption. Journal of Marketing Management, 28(3-4), p. 445-468

13. Prothero, A., Fitchett, J. A. (2000). Greening capitalism: Opportunities for a green commodity. Journal of Macromarketing, 20(1), p. 46-55.

14. Rettie, R., Burchell, K., Riley, D. (2012). Normalising green behaviours: A new approach to sustainability marketing. Journal of Marketing Management, 28(3-4), p. 420-444.

15. Kilbourne, W. E. (1998). Green marketing: A theoretical perspective. Journal of Marketing Management, 14(6), p. 641-655.

16. Peattie, K., Crane, A. (2005). Green marketing: Legend, myth, farce or prophesy? Qualitative Market Research: An International Journal, 8(4), p. 357-370.

17. Menon, A., Menon, A. (1997). Enviropreneurial marketing strategy: The emergence of corporate environmentalism as market strategy. The Journal of Marketing, 61(1), p. 51-67.

18. Gordon, R., Carrigan, M., Hastings, G. (2011). A framework for sustainable marketing. Marketing Theory, 11(2), p. 143-163.

\section{References}

1. Beck, W. (1992). Risk Society. Towards a New Modernity. London: Sage [in English].

2. Picou, J. S., Marshall, B. K. (2002). Contemporary conceptions of environmental risk: Implications for resource management and policy. Sociological Practice, 4(4), 293-313 [in English]

3. Hyett, D. (2010). Environmental risk assessment in environmental impact assessment-optional or mandatory? In IAIA10 Conference Proceedings: The Role of Impact Assessment in Transitioning to the Green Economy. 30th Annual Meeting of the International Association for Impact Assessment. (pp. 6-11) [in English]

4. Burkov, V. N., Novikov, D. A., Shhepkin, A. V. (2008). Mekhanizmy upravleniya ekologoekonomicheskimi sistemami [Mechanisms for the management of environmental and economic systems]. Moscow: Fizmatlit [in Russian].

5. Tepman, L. N. (2002). Riski v ekonomike [Risks in the economy]. Moscow: YUNITI [in Russian].

6. Shmal, A. G. (2010). Faktory ekologicheskoj opasnosti \& ekologicheskie riski [Environmental Hazards \& Environmental Risks]. Bronnitsy: «Bronniczkie novostiTelevidenie» [in Russian].

7. Kachinskiy, A. B. (2001). Ekologichna bezpeka Ukrayini: sistemnij analiz perspektiv pokrashhennya [Ecological Bezpeka of Ukraine: system analysis of prospects for abbreviation]. Kyiv: NISD [in Ukrainian].

8. Kozmenko, O. V. (2008). Strakhoviy rinok Ukrayini u konteksti staloho rozvytku [Ukraine's insurance market in the context of steel development]. Sumy: DVNZ "UABS NBU" [in Ukrainian].

9. Taranyuk, K. V. (2014). Orhanizatsiino-ekonomichni osnovy upravlinnia ekolohichnym ryzykom na rehionalnomu rivni [Organizational-economic basics of environmental management of the region on the regional level]. Candidate's thesis. Sumy: SumDU [in Ukrainian].

10. Karayeva, N. V., Vojtko, S. V., Sorokina, L. V. (2013). Ryzyk-menedzhment staloho rozvytku enerhetyky: informatsiina pidtrymka pryiniattia rishen [Rizikmanagement of steel energy development: information technology training]. Kyiv: Alfa Reklama. Retrieved from https://www.voytko.kpi.in.ua [in Ukrainian].

11. Belz, F. M., Peattie, K. (2009). Sustainability marketing: A global perspective. Chichester: Wiley [in English].

12. McDonald, S., Oates, C. J., Alevizou, P. J., Young, C. W., Hwang, K. (2012). Individual strategies for sustainable consumption. Journal of Marketing Management, 28(3-4), 445-468 [in English].

13. Prothero, A., Fitchett, J. A. (2000). Greening capitalism: Opportunities for a green commodity. Journal of Macromarketing, 20(1), 46-55 [in English].

14. Rettie, R., Burchell, K., Riley, D. (2012). Normalising green behaviours: A new approach to sustainability marketing. Journal of Marketing Management, 28(3-4), 420-444 [in English].

15. Kilbourne, W. E. (1998). Green marketing: 


\section{МАРКЕТИНГ}

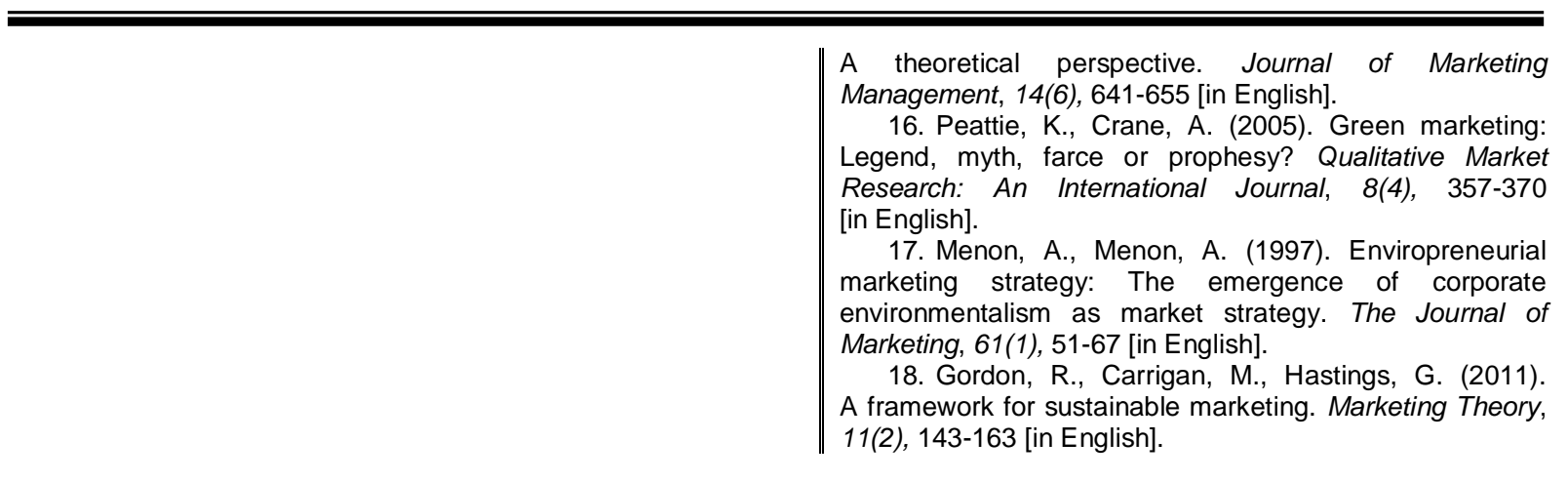

Надійшла 18.05.2020

Бібліографічний опис для цитування :

Коробець О. М. Бібліометричний аналіз взаємозв'язку понять «екологічний ризик» та «маркетинг». Науковий вісник Полісся. 2020. № 1 (20)., С. 104-110.

Коробець

Олена Михайлівна

Korobets

Olena Mykhailivna провідний фахівець кафедри маркетингу, Сумський державний університет;

https://orcid.org/0000-0001-6977-4280;

E-mail:e.korobets@fem.sumdu.edu.ua;

Leading specialist at the Department of Marketing, Sumy State University;

https://orcid.org/0000-0001-6977-4280;

E-mail:e.korobets@fem.sumdu.edu.ua. 